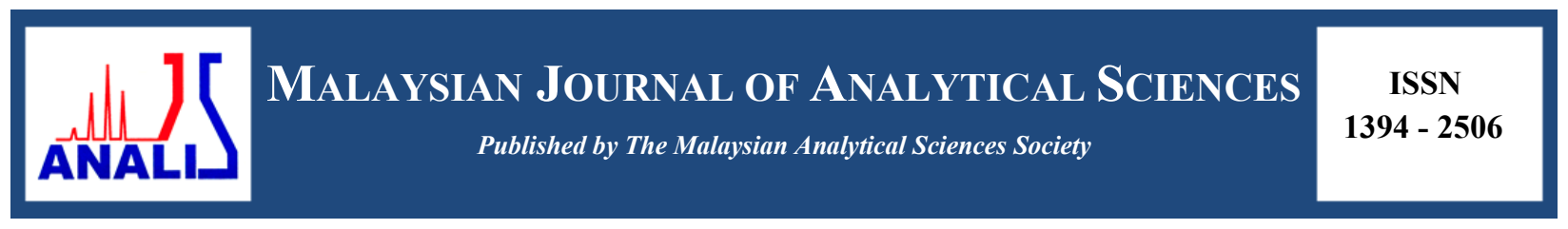

\title{
DETERMINATION OF TOTAL ORGANIC CARBON CONCENTRATION IN SURFICIAL SEDIMENTS OF SUNGAI PINANG, PENANG, MALAYSIA
}

\author{
(Penentuan Jumlah Karbon Organik dalam Sedimen Permukaan di Sungai Pinang, \\ Pulau Pinang, Malaysia) \\ Ong Meng Chuan*, Fok Fei Mei, Yong Jaw Chuen \\ School of Marine and Environmental Sciences \\ Universiti Malaysia Terengganu, 21030 Kuala Terengganu, Terengganu, Malaysia \\ *Corresponding author: ong@umt.edu.my
}

Received: 17 August 2015; Accepted: 11 October 2016

\begin{abstract}
The concentration of total organic carbon (TOC) and mean size sediment in a total of 24 samples of surficial sediment were determined. From the results of study, the concentration of TOC $(5.33 \%)$ was found high nearby the housing area at Sungai Pinang. At the downstream of the river tend to have higher concentration of TOC $(1.05 \%-5.33 \%)$ while at the upstream tend to have low degree of TOC in surficial sediments $(0.36 \%-0.78 \%)$. The major contribution in TOC contamination at the bottom part of the river maybe due to anthropogenic activities such as waste effluent from urban runoff, industrial activities and boat activities. Apart from that, the mean grain size was probably an important factor that influences the TOC content in surficial sediment at Sungai Pinang. This is because the distribution of the mean grain size that had similar trend to TOC. In addition, the high correlation relationship between TOC and mean grain size were observed and it had accounted for $r=0.67$ owing to fine particles of sediment which had provided a large binding capacity for the sorption of organic carbon. Moreover, fine sediment probably indicates slow hydrodynamic energy at the downstream. It might affect the chemical sorption process and allow the particulate organic carbon to accumulate at the bottom of the water column. Thus, fine sediment maybe playing dominant role in the content of TOC in surficial sediment at Sungai Pinang.
\end{abstract}

Keywords: total organic carbon, mean size sediment, surficial sediments, Sungai Pinang

\begin{abstract}
Abstrak
Kandungan jumlah karbon organik (TOC) dan purata saiz sedimen di dalam 24 sampel sedimen permukaan telah ditentukan. Dari hasil kajian ini, kepekatan TOC (5.33\%) didapati tinggi berhampiran dengan kawasan perumahan di Sungai Pinang. Di kawasan hilir sungai tersebut mempunyai kepekatan TOC yang lebih tinggi $(1.05 \%-5.33 \%)$ manakala di kawasan hulu sungai mempunyai kepekatan yang rendah dalam permukaan sedimen $(0.36 \%-0.78 \%)$. Kemungkinan punca utama untuk pencemaran TOC di bahagian hilir sungai adalah dari aktiviti antropogenik seperti sisa buangan daripada bandar, aktiviti perindustrian dan aktiviti bot. Selain itu, purata saiz partikel kemungkinan adalah faktor penting menpergaruhi kandungan TOC dalam sedimen permukaan di Sungai Pinang. Ini kerana taburan purata saiz partikel mempunyai corak yang sama dengan TOC. Tambahan pula, hubungan korelasi antara TOC dan purata saiz partikel didapati tinggi dalam sedimen permukaan, iaitu $r=0.67$ disebabkan saiz partikel yang halus memperolehi kapasiti pengikatan yang luas untuk penyerapan karbon organik. Selain itu, sedimen yang halus berkemungkinan menunjukkan tenaga hidrodinamik yang perlahan di bahagian hiliran. Hal ini berkemungkinan mempengaruhi proses penyerapan dan pengumpulan zarah karbon organik di bahagian bawah turus air. Oleh itu, sedimen yang halus berkemungkinan besar memainkan peranan yang paling dominan kepada kandungan TOC yang dalam sedimen permukaan di Sungai Pinang.
\end{abstract}

Kata kunci: jumlah karbon organik, purata saiz sedimen, sedimen permukaan, Sungai Pinang 


\section{Introduction}

In general, total organic carbon (TOC) includes all of organic carbon compounds contain in sediment [1,2]. The amount of organic matter that can be stored in river sediment is influenced by several factors, for instances, the types and sources of organic compounds introduced, sediment texture, grain particle size and sedimentation [3,4]. In previous sediment geochemical-related research studies, TOC has been proved to be playing a dominant controlling factor as it manipulates the distribution of other components, including chemical component and biological component in aquatic environment [1,5]. The quantity of organic and inorganic chemical contaminants in sediments such as hydrophobic organic compounds and total mercury respectively were reported to have high correlation with TOC $[6,7,8$,$] . This is because the organic matter is regulating the mobility of those pollutants in sediment [6,7,8]$. In addition, some researchers are calculating the fraction of TOC with total sulfur while some other researchers determine the relationship between TOC and total nitrogen for the purpose of evaluation of the type of sedimentary environment and elucidate the dynamic of organic matter in sediment $[2,3,9]$. Hence, TOC is one of the important chemical sediment quality measurements that has been widely used in environmental evaluation analysis $[1,8]$.

Surficial sediment was used as environment indicator in this present study. Surficial sediment is acting as the sink of TOC and other chemical pollutants as it is able to accumulate all the substances that have settled down on the bottom of water column, including particulate organic carbon and sediment particles which is attached with organic carbon substance $[3,5,9]$. Thus, surficial sediment is capable of reflecting the latest deposited pollution history $[2,10]$. On one hand, the strength of preservation of chemical components in surficial sediment is much greater and consistence [10]. However, some contaminants in sediment may return into water system if there is an environmental alteration [10]. Therefore, surficial sediment has been widely used as environmental tool by researchers.

It is important to determine the TOC content at Sungai Pinang because it is one of seven most contaminated river basins in Malaysia according to the Department of Environment (DOE) [11,12]. Based on National Water Quality Standards for Malaysia (NWQS), the water quality of Sungai Pinang basin was classified under IV which is very polluted in year 1999 [13]. In addition, previous study by Saad et al. [13] had concluded that the water quality of Sungai Pinang had degraded and was classified under V showing a very high level of chemical oxygen demand (COD) which was $1219.33 \mathrm{mg} / \mathrm{L}$, very low in dissolved oxygen (DO) which account for $<1.0 \mathrm{mg} / \mathrm{L}$ and the temperature $\left({ }^{\circ} \mathrm{C}\right.$ ) of water was not categorized in normal range. Apart of that Sungai Pinang is surrounded by heavy industrial and urban areas, the river mouth is an important channel in the distribution of carbon matters [9,14]. Thus, the surficial sediment of Sungai Pinang is exposure to various chemical compound contamination which is contained in the bottom of the water.

In the recent years, Malaysia Environment Quality report (2012) showed that the water quality in Sungai Pinang estuary had improved to class ÏII [15]. However, chemical pollutants that is adsorbed onto the surface sediment, both inorganic and organic pollutants might be released back into water column if there is a sudden change in water quality [2,5]. The increment of toxicity level of pollutants eventually will give adverse impacts on the entire food web in the aquatic ecosystem [3,5]. Therefore, determination of TOC content (\%) in the surface sediment is a vital piece of information to Department of Environment (DOE) or policy maker to take further actions in minimizing the anthropogenic discharge.

In the light of these reasons, the aim of the present study is to determine the concentration of TOC (\%) in surface sediments at Sungai Pinang. Those results can be established as a baseline assessment of sediment quality. In addition, particle size of sediment is playing an important role in controlling the concentration of chemical components in sediment $[5,16]$. Therefore, the second objective is to reveal the relationship between TOC (\%) and mean size sediments $(\varnothing)$.

\section{Materials and Methods}

\section{Study area}

The sampling location is at Sungai Pinang ( $5^{\circ} 24^{\prime} \mathrm{N} ; 100^{\circ} 19^{\prime}$ E) located in Penang Island, which situated in the northeast of Peninsular Malaysia (Figure 1). This research study was carried out on $20^{\text {th }}$ of July in year 2013 . In 
order not to miss any hotspot that might contain extreme level of TOC, a total of 24 sampling stations was deployed along Sungai Pinang that is about $100 \mathrm{~m}$ apart from each other (Figure 2). The distance between P1 and P21 are about $2.47 \mathrm{~km}$. The total area of Sungai Pinang basin is about $50.97 \mathrm{~km}^{2}[13,17,18]$. According to Malaysian Meteorological Department (MMD), Malaysia was having dry weather condition with low rainfall distribution that had accounted for less than $200 \mathrm{~mm}$ of precipitation in July of year 2013. Sungai Pinang was surrounded by $70 \%$ of wet markets with warehouses, small industrial facilities, residential areas, slaughter houses, and working areas which have a potential to release high amount of waste and toxic chemicals $[13,17]$.

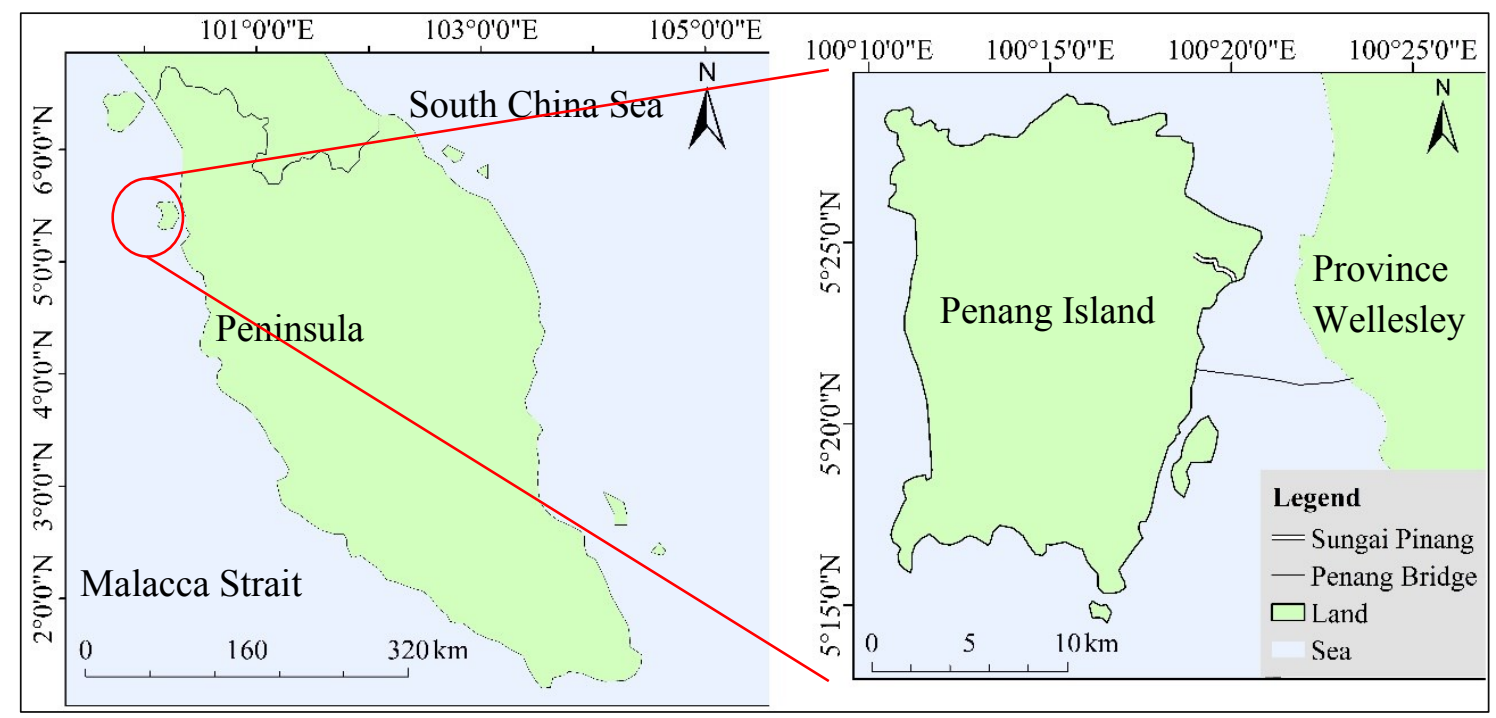

Figure 1. Sampling activity was conducted at Penang Island which is located at Northeast of Peninsular Malaysia

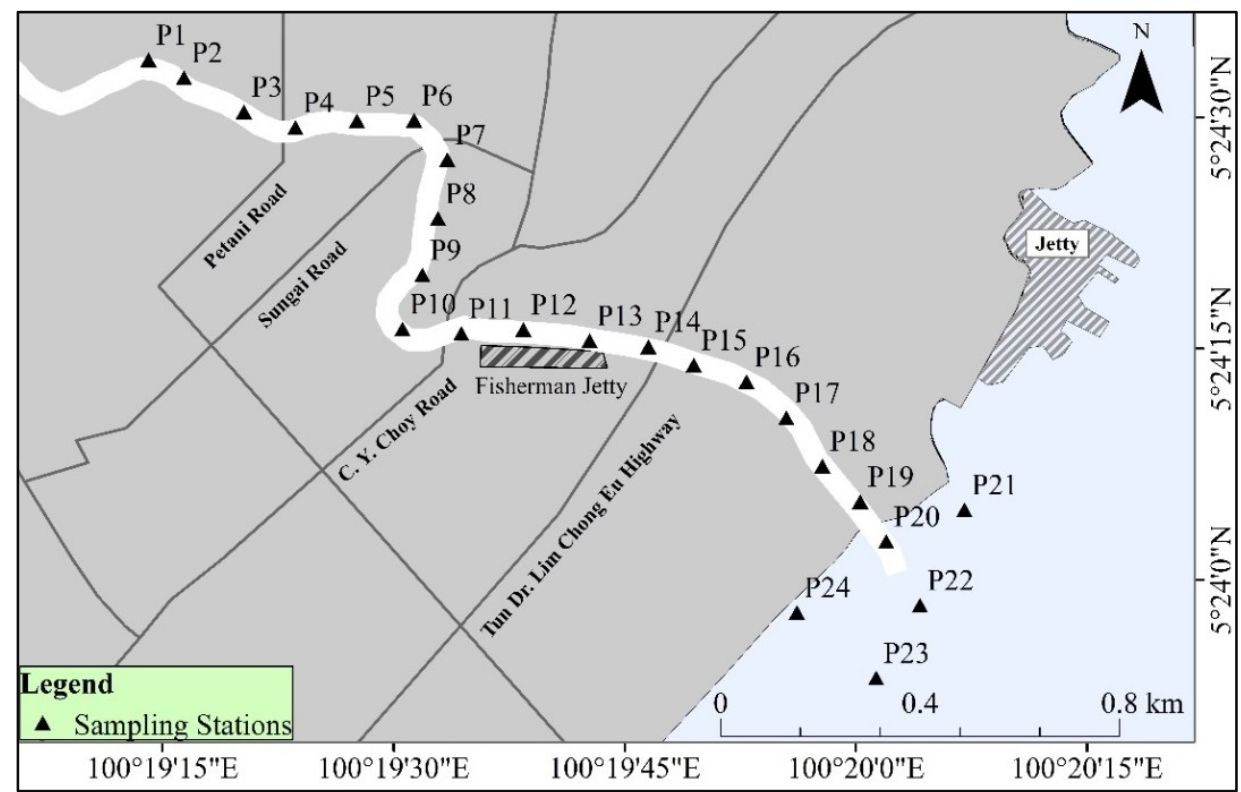

Figure 2. A total of 24 sampling locations was deployed along Sungai Pinang and its river mouth in Penang Island, Penang, Malaysia 
For preparation of sampling activity, all apparatus including plastic spoon and polythene bag were cleaned with $10 \%$ of nitric acid and rinsed with distilled water. About $5 \mathrm{~cm}$ depth of the surface sediment samples were collected by Ponar grab. Precaution was taken to make sure the grab is firmly closed to ensure the maximum preservation of fine sediments samples, so that the reading for the size fractions of sediment is accurate [19]. The actual coordinate of sampling stations is recorded by using Global Positioning System (GPS). In order to minimize the chemical and biological reaction, sediments samples were kept at low temperature $\left(<4{ }^{\circ} \mathrm{C}\right)$ in an ice-box during sampling and is stored in a freezer after it is transferred back to the laboratory $[19,20]$. The sediment samples were dried using oven at $60{ }^{\circ} \mathrm{C}$ and weighed using electronic balance until consistency of samples weight was achieved [20]. The dried sediment samples were proceeded into two separate analyses.

\section{Extraction method for total organic carbon}

Wet oxidation method by means of titration was used to determine the TOC content in surficial sediment as it is simple, low in costing, and less equipment is needed for titration [21]. A total of $10 \mathrm{~mL}$ of $1 \mathrm{~N}$ potassium dichromates $\left(\mathrm{K}_{2} \mathrm{Cr}_{2} \mathrm{O}_{7}\right)$ was added into $0.5 \mathrm{~g}$ of sediments samples, standard solution $(0.03 \mathrm{~g}$ of glucose $)$ and blank solution (cleaned boiling tube) separately. Next, $20 \mathrm{~mL}$ of concentrated sulphuric acid $\left(\mathrm{H}_{2} \mathrm{SO}_{4}\right)$ was added into the mixture. If the mixture sediments samples had changed into green color, $5 \mathrm{~mL}$ of $\mathrm{K}_{2} \mathrm{Cr}_{2} \mathrm{O}_{7}$ will be added subsequently to ensure the mixture turn brown. The total volume of $\mathrm{K}_{2} \mathrm{Cr}_{2} \mathrm{O}_{7}$ was recorded.

The mixtures were then heated to complete the digestion process for 30 minutes by using boiling bath water on a laboratory hot plate. Once 30 minutes is up, all the boiling tubes were set aside for cooling to allow the exothermic reaction to take place. The mixtures were rinsed with $200.0 \mathrm{~mL}$ of distilled water and transferred into Erlenmeyer flask (Standard solution and Blank solution should go through titration first before the titration of sediments sample solution). A volumes of $10.0 \mathrm{~mL}$ phosphoric acid $\left(\mathrm{H}_{3} \mathrm{PO}_{4}\right)$ and $1 \mathrm{~mL}$ of indicator diphenylamine $\left(\mathrm{C}_{6} \mathrm{H}_{5} .2 \mathrm{H}_{2} \mathrm{O}\right)$ were added into the Erlenmeyer flask. A dark blue solution was observed.

The initial reading of the volume of Ferrous Sulfate $\left(\mathrm{Fe}_{2} \mathrm{SO}_{4} \cdot 7 \mathrm{H}_{2} \mathrm{O}\right)$ in the burette was recorded. The mixtures were then titrated with $\mathrm{Fe}_{2} \mathrm{SO}_{4} \cdot 7 \mathrm{H}_{2} \mathrm{O}$ and mixed well with Orbital shaker. End point was reached when the solution turn into a light green in color [6]. The final reading for the volume of $\mathrm{Fe}_{2} \mathrm{SO}_{4} .7 \mathrm{H}_{2} \mathrm{O}$ in burette was recorded. Percentage of carbon for glucose solution (Standard solution) was approximately $36 \pm 5 \%$. The calculation formula was applied to obtain percentage (\%) of organic carbon, as shown in equation 1 below:

$$
\text { Organic Carbon }(\%)=\frac{(V 1-V 2) \times 0.003 \times 100}{\text { Weight of sample }(\mathrm{g})}
$$

Where V1 is define as Volume of Potassium dichromate used $(\mathrm{mL})$, V2 is define as Volume of Ferrous sulfate titrated $(\mathrm{mL})$ and $10 \mathrm{~mL}$ of dichromate and $3 \mathrm{mg}$ of carbon $=0.003 \mathrm{~g}$ carbon

\section{Sediment characteristic analysis method for coarse sediment}

Dry sieve method was used to determine the mean size of coarse sediment. A total of $200 \mathrm{~g}$ of dried sediment was sieved by using Sieves and Shaker for 10 minutes. A total of 14 different mesh size sieves was arranged consecutively downward from larger mesh size to fine size as follows: $4000 \mu \mathrm{m}, 2800 \mu \mathrm{m}, 2000 \mu \mathrm{m}, 1400 \mu \mathrm{m}$, $1000 \mu \mathrm{m}, 710 \mu \mathrm{m}, 500 \mu \mathrm{m}, 355 \mu \mathrm{m}, 250 \mu \mathrm{m}, 18 \mu \mathrm{m}, 125 \mu \mathrm{m}, 90 \mu \mathrm{m}, 63 \mu \mathrm{m}$ and $<63 \mu \mathrm{m}$. Sediment samples retained in each layer of sieve were weighted by using an electronic balance. The reading of weight in each sieve was recorded [22]. Mean value can be computed by a moment method, as shown in equation 2 below:

$$
\text { Mean }(\varnothing)=\frac{\sum \mathrm{fm}}{n}
$$

where $\mathrm{f}$ is defined as percentage weight of each grade of particle size (\%), $\mathrm{m}$ is median of each particle in size in $\varnothing$ and $n$ is defined as total number of sample in 100 when $\mathrm{f}=\%$

\section{Sediment characteristic analysis method for fine sediment}

Laser diffraction method was used for the determination of the mean size of fine sediment. A total of $1.5 \mathrm{~g}$ of sediment samples was transferred into a centrifuge tube and $5 \mathrm{~mL}$ of $10 \%$ of Calgon solution was added. The 
Calgon solution was used to disperse the bonded particle sediments [23]. The mixture was then topped up with distilled water to $50 \mathrm{~mL}$ and the grain size sediments were analyzed by using Particle Size Analyzer (PSA) [24].

\section{Results and Discussion}

Figure 3 shows the distribution of TOC (\%) in surficial sediments of Sungai Pinang. According to the figure, the range was from $0.36 \%$ at $\mathrm{P} 4$ to $5.33 \%$ at $\mathrm{P} 10$ with the mean of $2.16 \%$. The trend of TOC (\%) remained steady at the upstream zone (from P1 to P9) and followed by a sharp rise at P10. The content of TOC remained constant and followed by a gradual decreased after P20. Housing area was observed at nearby P10 which had the highest TOC concentration at the studied river which is $5.33 \%$. Additionally, there were a high number of fishing boats nearby P12 during sampling activities. In overall, the downstream zone of the river (from P13 to P24) showed that it was having high mean value of TOC concentration which accounted for 3.04\% in comparison with upstream zone of the river, $1.28 \%$ (from P1 to P12).

TOC concentration is one of the measurements to estimate the amount of organic matters preserved in sediment $[1,25]$. The contribution of high in TOC concentration at Sungai Pinang might possibly be coming from the continuous deposit of organic matter from terrestrial, dead organisms, urban runoff, untreated waste effluent from industrial factories $[1,25,26]$. Additionally, variety of chemical wastes, for instance, fuel oil from boat activities which is shown at P12 was probably a major contributor of TOC concentration in surficial sediment [27,28]. This phenomenon can be seen at the Cape Town harbor which had an intense vessel traffic. It had suggested that the wastes discharges from shipping activities might be cause the elevated level of TOC concentration in surficial sediments [28]. In addition, it has been reported that high correlation relationship between total petroleum hydrocarbon and TOC concentration in surficial sediment was observed [27]. According to the research done by Ali et al. [27], it had mentioned that the possible sources of elevation in total petroleum hydrocarbon was closely related to shipping activities and it promotes the deposition of TOC content in surficial sediments.

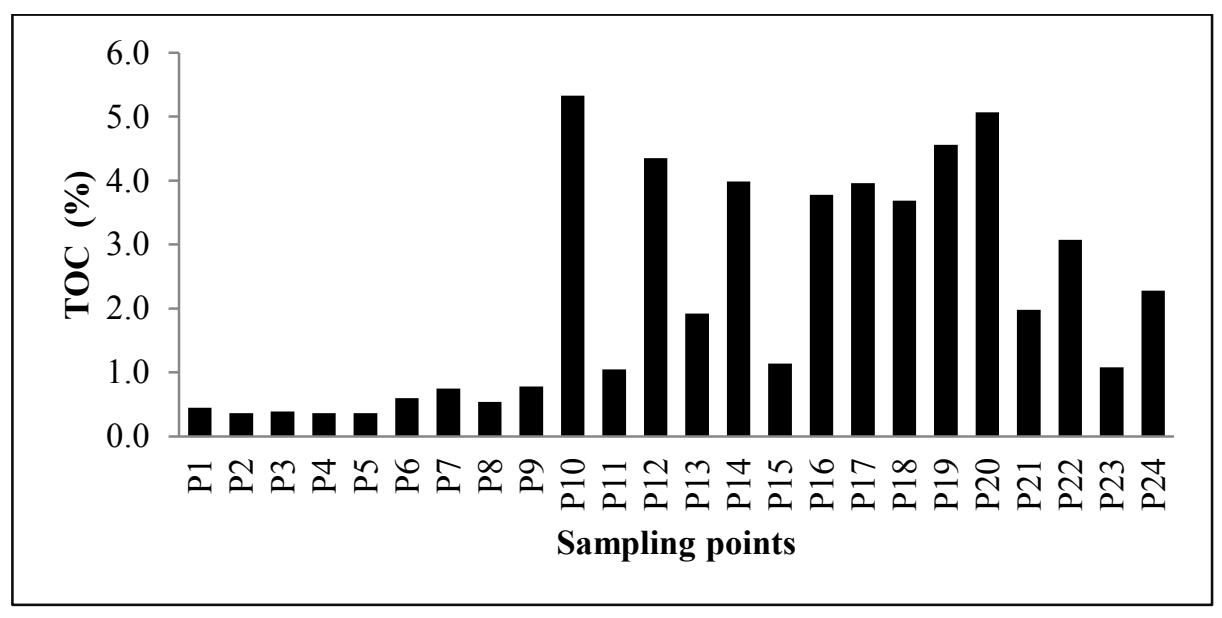

Figure 3. Distribution of TOC (\%) in surficial sediments of Sungai Pinang, Penang

Apart from that, grain size sediment would be playing an important role which affects the organic matter bound to surface sediments [25,29]. The fine sediments have been known to be a preference for sorption of chemical compound $[4,25,30]$. Hence, it is indicated that sediment at lower catchment might possibly have wider surface area to volume ratio of binding site for organic compounds absorption [20,30]. In addition, fine particle sediment may denote slow hydrodynamic energy and particulate $\mathrm{OC}$ in water column have enough time to be absorbed on surficial sediment $[20,30]$. 
After P20 which is located at the river mouth, it tends to have a lower concentration of TOC and this phenomenon is similar to the estuary of Mahi River, India. Dinakaran and Krishnayya [14] had suggested that the sediment in the estuary might be affected by backwater system. In addition, the other physical components including tidal alteration might influence the level of TOC in sediments at river mouth [2].

The effect of high content of OC in surficial sediment might have contributed to the depletion of DO at the bottom of water column at the downstream of Sungai Pinang [1]. This is because high number of organic matter is promoting the growth of anaerobic bacteria which needs the DO to carry out their microbial activities $[1,7]$.

Although high content of organic matter in aquatic environment may not contribute to a significant threat to human health, it will enhance the synergic effects when it is associated with other chemical compounds and nutrient availability [3,5,7]. It has been reported that TOC concentration is one of the important chemical factors that regulates the behavior of other chemical components in sediments [1,2,5]. Thus, determination of TOC concentration in surficial sediment is taken into the account of environment characteristic analysis $[1,2]$.

The comparison concentration of TOC (\%) in surficial sediment of Sungai Pinang and other regions are shown in Table 1. From the table compassion, Sungai Pinang recorded higher TOC level compared to other rivers such as Sungai Klang basin [31], Sungai Langat [32], Yangtze Estuary [33], Changhua River Estuary [34], Pearl River Estuary [35], Danube River [36] and Beijiang River [37] except Port Klang in Malaysia [20]. Different environmental condition of each study location might probably give different results on TOC content in the surficial sediment. Port Klang, Malaysia has the highest concentration of TOC compared to present study as it reported that the source of TOC concentration probably caused by the discharge of chemical contaminants from shipping area and industrial wastes, weak water current as well as high portion of fine-sized grains sediments [20]. Thus, the fine grain size might be acting as synergic effects in concentration of TOC.

Table 1. Comparison of concentration TOC in surface sediments of Sungai Pinang to published data from similar habitat environments

\begin{tabular}{lcl}
\hline Area & TOC (\%) & References \\
\hline Sungai Pinang & $2.16-5.33(2.16)$ & Present study \\
Malaysia Region & & \\
Sungai Klang & $0.19-4.5$ & {$[31]$} \\
Port Klang, Selangor & $5.35-24.88$ & {$[20]$} \\
Sungai Langat & $0.08-3.42$ & {$[32]$} \\
Others Region & & \\
Yangtze Estuary, China & $0.098-0.82(0.436)$ & {$[33]$} \\
Changhua River Estuary, China & $0.01-0.88(0.55)$ & {$[34]$} \\
Pearl River Estuary & $0.48-1.14$ & {$[35]$} \\
Danube River, Serbia & $0.2-2.82$ & {$[36]$} \\
Beijing River, China & $1.29 \pm 0.82$ & {$[37]$} \\
\hline
\end{tabular}

Figure 4 shows the sediments mean size (Ø) in surficial sediments of Sungai Pinang. The mean grain size was classified according to Wentworth size class [38]. From the grain size sediments analysis, the largest particle size of sediments was recorded at P2 in which is under the coarse grain size category $(-0.67 \varnothing)$, while the finest particle size of sediments was located at P23 (5.46Ø) which was classified as medium silt. The average of mean size of sediments of the 24 sampling stations at Sungai Pinang was 2.63Ø. The trend showed the particle size of sediments decreases gradually from upstream of river towards river mouth. 
The upper river catchment had higher composition of coarse sediments compared to downstream. According to $[2,20]$, the environmental changes of river such as transportation and process of sedimentary as well as distribution of material input would affect the grain size of sediments. Additionally, upstream zone tends to have coarser grain size sediments which have a higher possibility of strong hydraulic energy which causes the fine sediment particles to have a shorter residence time which reduces the deposits at the bottom of water column [4,33,39]. Moreover, silt and clay have more loose fabric with higher degree of porosity and permeability, which is easier to be transported to downstream and leave coarser sediments on the river bed $[25,40]$.

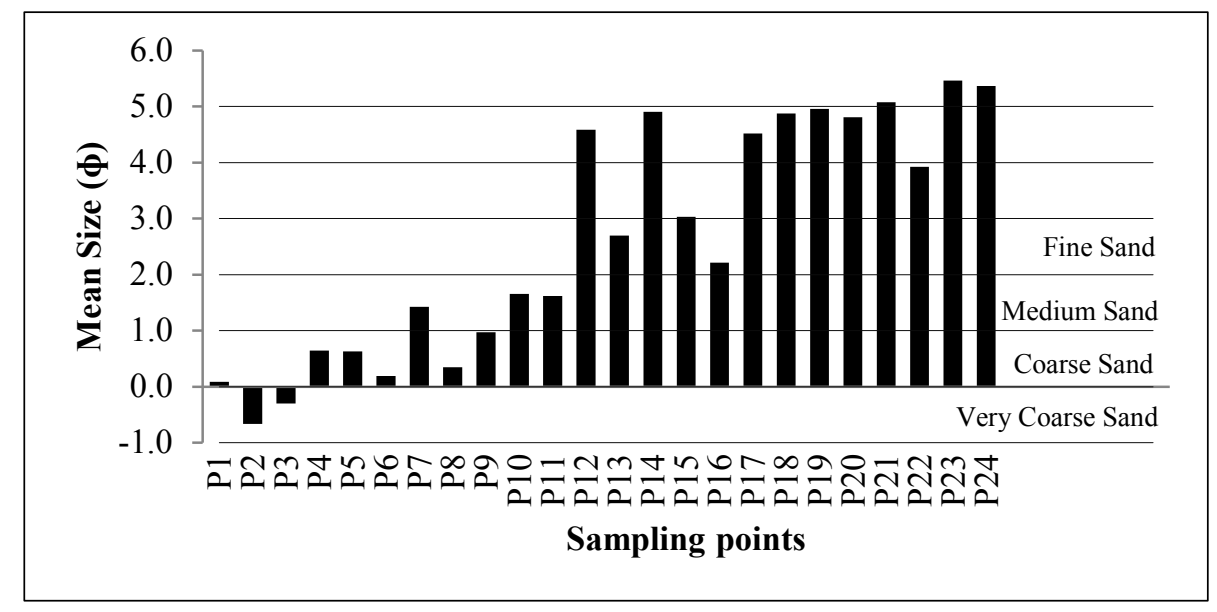

Figure 4. Variation of mean sediment size (Ø) in surficial sediments of Sungai Pinang, Penang

The type of surface sediments at Sungai Pinang varies from coarse sand to medium silt. Figure 5 shows the average sediments texture percentage (\%) in surficial sediments of Sungai Pinang. The trend of sand grain size $(63-2000$ $\mu \mathrm{m})$ decreases towards the river mouth while for the trend of silt and clay grain size is shown to be vice versa. From the result of sediments texture percentage (\%), it was shown that the highest proportion for the category of silt grain size $(4-63 \mu \mathrm{m})$ was found at P23 which was accounted for $81.39 \%$ whereas for the category of clay grain size $(<4$ $\mu \mathrm{m}$ ) was found in $\mathrm{P} 21,4.72 \%$ was observed.

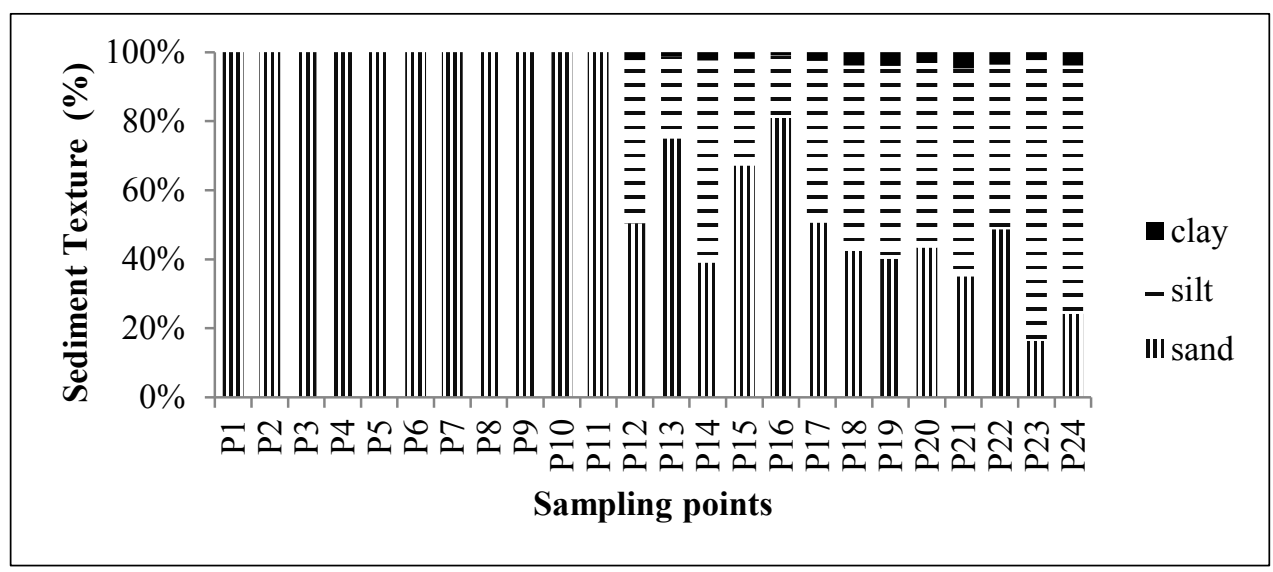

Figure 5. An average percentage sediments texture (\%) in surficial sediments of Sungai Pinang, Penang 
Downstream tend to have high proportion of slit and clay grain size sediments. It indicates that it might have a low hydrodynamic condition at the estuary [20,30]. The low water flow condition leads to sediments being suspended in water column to have more time to sink and redeposited at the bottom [20]. The consequences of river transportation were found in many rivers such as Klang River [20], Juru River, Malaysia [41] and Keelung River drainage basin, Taiwan [42] Furthermore, estuary has been well known as a settlement for sedimentation during tidal period and tends to have higher sedimentation rate $[20,41]$.

Generally, fine particle sediments are well known as dominant controlling factors to regulate the TOC concentration in surficial sediment $[14,20,33]$. Figure 6 shows the correlation relationship of high percentage of TOC concentration is directly proportional to fine sediments size and it is accounted for $r=0.67$. It was suggesting that the finer grain size sediments might be a significant factor in controlling the TOC content in surficial sediments at Sungai Pinang $[14,20,34]$. This is because the fine sediments are providing a larger specific surface area and binding sites for organic carbon absorption [4,33,40]. This phenomenon also can be seen at Port Klang, Malaysia as it is reported that the fine grain size sediment had a significant positive correlation with TOC concentration [20].

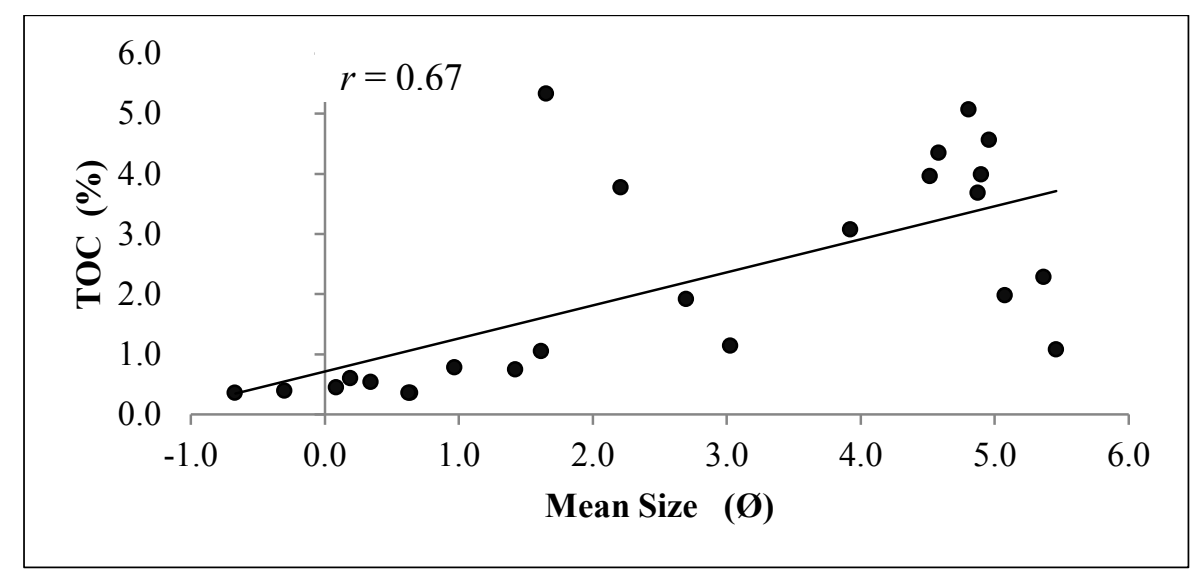

Figure 6. Correlation between TOC (\%) and mean sediments size (Ø) in surficial sediments of Sungai Penang

\section{Conclusion}

In conclusion, the highest concentration of TOC (5.33\%) at Sungai Pinang was found nearby housing area. At the downstream of Sungai Pinang tend to have a high concentration of TOC $(1.05 \%-5.33 \%)$. This is because the fine particle of sediments had provided larger binding sites to organic carbon for absorption. Apart from that, the fine sediments were probably denoted slow hydrodynamic energy at the downstream. It might strengthen the absorption process and lead to accumulation of TOC at the bottom of water column. Thus, the grain size sediment might be playing an important role as controlling factor of concentration of TOC in surficial sediments at Sungai Pinang. The results of present study are a necessity in making assessment of sediment quality and ecological risk. This is because the TOC is one of the controlling factors in regulating the chemical and biological compounds in surficial sediments. The chemical organic and inorganic pollutants such as polycyclic aromatic hydrocarbons (PAHs) and heavy metals respectively in surficial sediments can be the secondary source of water pollution if there is an environmental change. Consequently, it will give a deleterious health effects on living organisms in aquatic environment.

\section{Acknowledgement}

This research was conducted with funding from the Ministry of Higher Education Malaysia (MOHE), under the Niche Area Research Grant Scheme (NRGS) project number 53131 and Fundamental Research Grant Scheme (FRGS) 59299. The authors wish to express their gratitude to Oceanography and Biodiversity Laboratory, School of Marine and Environmental Sciences teams for their invaluable assistance and providing the facilities to carry out 
the research. We are grateful to our editors and referees for their invaluable comments that helped improve this manuscript.

\section{References}

1. Lazăr, L., Gomoiu, M.T., Boicenco, L. and Vasili, D. (2012). Total organic carbon (TOC) of the surface layer sediments covering the seafloor of the Romanian black sea. Geo-Eco-Marina, 18: 121 - 132.

2. Hossain, G. M. and Bhuiyan, M. A. H. (2016). Spatial and temporal variations of organic matter contents and potential sediment nutrient index in the sundarbans mangrove forest, Bangladesh. KSCE Journal of Civil Engineering, 20 (1): $163-174$.

3. Anawar, H. M., Yoshioka, T., Konohira, E., Akai, J., Freitas, M. C. and Tareq, S. M. (2010). Sources of organic carbon and depositional environment in the Bengal delta plain sediments during the holocene period. Limnology, 11 (2): 133 - 142.

4. Manju, M. N., Resmi, P., Kumar, Ratheesh, C. S., Gireeshkumar, T. R., Chandramohanakumar, N. and Joseph, M. M., (2016). Biochemical and stable carbon isotope records of mangrove derived organic matter in the sediment cores. Environmental Earth Sciences, 75: 565 - 580.

5. Naji, A., Ismail, A. and Ismail, A. R. (2010). Chemical speciation and contamination assessment of $\mathrm{Zn}$ and Cd by sequential extraction in surface sediment of Klang River, Malaysia. Microchemical Journal, 95 (2): 285 292.

6. Kwaansa-Ansah, E. E., Voegborlo, R. B., Adimado, A. A., Ephraim, J. H. and Nriagu, J. O. (2012). Effect of $\mathrm{pH}$, sulphate concentration and total organic carbon on mercury accumulation in sediments in the volta lake at yeji, ghana, Bulletin of Environmental Contamination and Toxicology, 88 (3): 418 - 421.

7. Shoham-Frider, E., Azran, S. and Kress, N. (2012). Mercury speciation and total organic carbon in marine sediments along the Mediterranean coast of Israel. Bulletin of Environmental Contamination and Toxicology, 63 (4): $495-502$.

8. Hall Jr, L. W. and Anderson, R. D. (2014). Relationship of bifenthrin sediment concentrations to grain size and total organic carbon in California waterbodies: Implications for ecological risk. Bulletin of Environmental Contamination and Toxicology, 93 (6): $764-768$.

9. Zhao, C., Liu, S., Dong, S., Isange, S., Liu, Q., An, N. and Li, X. (2015). Spatial and seasonal dynamics of organic carbon in physically fractioned sediments associated with dam construction in the middle LancangMekong River. Journal of Soils and Sediments, 15 (11): 2323 - 2333.

10. Mei, J., Li, Z., Sun, L., Gui, H. and Wang, X. (2011). Assessment of heavy metals in the urban river sediments in Suzhou City, Northern Anhui Province, China. Procedia Environmental Sciences, 10: 2547 - 2553.

11. Daud, H. (2008). The water quality monitoring system/ program \& pollution control. Retrieved from Water Environment Partnership in Asia Web Site: http://www.wepa-db.net/pdf/0810malaysia/f.pdf

12. Usali, N. and Ismail, M. H. (2010). Use of remote sensing and GIS in monitoring water quality. Journal of Sustainable Development, 3 (3): 228 - 238.

13. Saad, F. N., Rahman, N. N., Kadir, M. O. and Omar, F. M. (2008). Identification of pollution sources within the Sungai Pinang River Basin. Proceeding of the Malaysian Research Group International Conference, Manchester, United Kingdom: pp. $478-485$.

14. Dinakaran, J. and Krishnayya, N. S. R. (2011). Variations in total organic carbon and grain size distribution in ephemeral river sediments in Western India. International Journal of Sediment Research, 26 (2): 239 - 246.

15. Department of Environment (2012). Malaysia Environment Quality Report. Department of Environment Malaysia: pp. 112.

16. Meng, J., Yao, P., Yu, Z., Bianchi, T. S., Zhao, B., Pan, H. and Li, D. (2014). Speciation, bioavailability and preservation of phosphorus in surface sediments of the Changjiang estuary and adjacent East China Sea inner shelf. Estuarine, Coastal and Shelf Science, 144: $27-38$.

17. Maznah, W. O. and Mansor, M. (2002). Aquatic pollution assessment based on attached diatom communities in the Pinang River basin, Malaysia. Hydrobiologia, 481(1): 229 - 241.

18. Misnan, N. and Rindam, M. (2012). Morfometri lembangan sungai-sungai utama di Pulau Pinang. Malaysia Journal of Society and Space, 8(3): $71-81$.

19. Ong, M., Menier, D., Shazili, N. and Kamaruzzaman, B. (2013). Geochemical characteristics of heavy metals concentration in sediments of Quiberon Bay waters, South Brittany, France. Oriental Journal of Chemistry, 29 (1): $39-45$. 
Ong et al: DETERMINATION OF TOTAL ORGANIC CARBON CONCENTRATION IN SURFICIAL SEDIMENTS OF SUNGAI PINANG, PENANG, MALAYSIA

20. Sany, S. B., Salleh, A., Rezayi, M., Saadati, N., Narimany, L. and Tehrani, G. M. (2013). Distribution and contamination of heavy metal in the coastal sediments of Port Klang, Selangor, Malaysia. Water, Air, and Soil Pollution, 224 (4): $1-18$.

21. Tung J. W. T. and Tanner, P. A. (2003). Instrumental determination of organic carbon in marine sediment. Marine Chemistry, 80 (2-3): $161-170$.

22. Folk, R. L. (1980). Petrology of sedimentary rocks Austin: University of Texas Libraries

23. Ong, M. C., Kamaruzzaman, B. Y., Shazili, N. A. and Rosnan, Y. (2006). Distribution and normalization of lead, copper and zinc in Terengganu, Malaysia. Journal Sustainability Science and Management, 1: 74 - 84.

24. Plumb, R. H. (1981). Procedures for handling and chemical analysis of sediment and water samples. Retrieved from United State Environmental Protection Agency: http://yosemite.epa.gov/r10/CLEANUP.NSF/ph/ T4+Technical+Documents $/ \$ F$

25. Özkan, E. Y. (2012). A New assessment of heavy metal contaminations in an eutrophicated bay (Inner Izmir Bay, Turkey). Turkish Journal of Fisheries and Aquatic Sciences, 12: 135-147.

26. Swarnalatha, K., Letha, J. and Ayoob, S. (2013). An investigation into the heavy metal burden of AkkulamVeli Lake in South India. Environmental Earth Sciences, 68 (3): 795 - 806.

27. Ali, S. A. M., Payus, C. and Ali, M. M. (2015). Surface sediment analysis on petroleum hydrocarbon and total organic carbon from coastal area of Papar to Tuaran, Sabah. Malaysian Journal of Analytical Sciences, 19 (2): $318-324$.

28. Okoro, H. K., Fatoki, O. S., Adekola, F. A., Ximba, B. J. and Snyman, R. G. (2016). Spatio-temporal variation of organotin compounds in seawater and sediments from Cape Town Harbour, South Africa using gas chromatography with flame photometric detector (GC-FPD). Arabian Journal of Chemistry, 9 (1): 95 - 104.

29. Mulligan, C., Fukue, M. and Sato, Y. (2010). Sediment contamination and sustainable remediation. London: CRC Press.

30. Li, G., Cao, Z., Lan, D., Xu, J., Wang, S. and Yin, W. (2007). Spatial variations in grain size distribution and selected metal contents in the Xiamen Bay, China. Environmetal Geology, 52 (8): 1559 - 1567.

31. Naji, A. and Ismail, A. (2011). Assessment of metals contamination in Klang River surface sediments by using different indexes. EnvironmentAsia, 4(1): 30 - 38.

32. Adnan, N. H., Zakaria, M. P., Juahir, H. and Ali, M. M. (2012). Faecal sterols as sewage markers in the Langat River, Malaysia: Integration of biomarker and multivariate statistical approaches. Journal of Environmental Sciences, 24(9): $1600-1608$.

33. Zhao, S., Feng, C., Wang, D., Liu, Y. and Shen, Z. (2013). Salinity increases the mobility of Cd, Cu, Mn, and $\mathrm{Pb}$ in the sediments of Yangtze Estuary: Relative role of sediments' properties and metal speciation. Chemosphere, 91 (7): 977 - 984.

34. Hu, B., Cui, R., Li, J., Wei, H., Zhao, J., Bai, F., Song, W. and Ding, X. (2013). Occurrence and distribution of heavy metals in surface sediments of the Changhua River estuary and adjacent shelf (Hainan Island). Marine Pollution Bulletin, 76 (1-2): 400 - 405.

35. Wang, F., Wang, W. X. and Huang, X. P. (2012). Spatial distribution of gut juice extractable $\mathrm{Cu}, \mathrm{Pb}$ and $\mathrm{Zn}$ in sediments from the Pearl River Estuary, Southern China. Marine Environmental Research, 77: 112 - 119.

36. Relić, D., Đorđević, D. and Popović, A. (2011). Assessment of the pseudo total metal content in alluvial sediments from Danube River, Serbia. Environmental Earth Science, 63(6): 1303 - 1317.

37. Chen, L. G., Huang, Y. M., Peng, X. C., Xu, Z., Zhang, S., Ren, M., Ye, Z. and Wang, X. (2009). PBDEs in sediments of the Beijiang River, China: Levels, distribution, and influence of total organic carbon. Chemosphere, 76 (2): $226-231$.

38. Wentworth C. K. (1922). A scale of grade and class terms for clastic sediments. Journal of Geology, 30: 377 392.

39. Satpathy, K. K., Mohanty, A. K., Prasad, M. V., Natesan, U. and Sarkar, S. K. (2012). Studies on the variations of heavy metals in the marine sediments off Kalpakkam, East Coast of India. Environmental Earth Science, 65 (1): $89-101$.

40. Kamaruzzaman, Y. and Ong., M. C., (2009). Geochemical proxy of some chemical elements in sediments of Kemaman River estuary, Terengganu, Malaysia. Sains Malaysiana, 38 (5): 631 - 636.

41. Idriss, A. A. and Ahmad, A. K. (2013). Heavy metals nickel and chromiumin sediments in the Juru River, Penang, Malaysia. Journal of Environmental Protection, 7: 1245 - 1253. 
42. Huang, K. M. and Lin, S. (2003). Consequences and implication of heavy metal spatial variations in sediments of the Keelung River Drainage basin, Taiwan. Chemosphere, 53 (9): 1113 - 1121. 